Vol 11, Issue 8, 2018

\title{
ARTEMISININ CONTENT ON ARTEMISIA ANNUA L. TREATED BY GLORIOSA SUPERBA SEEDS' WATER EXTRACT
}

\author{
SRI INDAH R ${ }^{1}$, ARI SUSILOWATI ${ }^{1}$, YULI WIDYASTUTI ${ }^{2}$, AHMAD YUNUS ${ }^{3 *}$ \\ ${ }^{1}$ Department of Bioscience, Graduate School, University of Sebelas Maret, Surakarta, Indonesia. ${ }^{2}$ Research and Development Center for \\ Medicinal Plant and Traditional Drug. ${ }^{3}$ Department of Agrotechnology, Faculty of Agriculture, University of Sebelas Maret, Surakarta, \\ Indonesia. Email: yunus.uns7@yahoo.com
}

Received: 09 March 2018, Revised and Accepted: 23 April 2018

ABSTRACT

Objective: The aim of this study was to determine the artemisinin content on Artemisia annua L. treated by water extract of Gloriosa superba seeds.

Methods: G. superba seeds obtained naturally on Krakal Beach, Gunung Kidul, and extraction used a maceration method by water solvent (1:1). A. annua L. sprouts were obtained from B2P2T00T Tawangmangu. Treatment variables done on sprouts using various water extract concentration of $G$. superba seeds and soaking time on A. annua L. sprouts. Determination of artemisinin content in leaf extract of $A$. annua L. was done using KLTdensitometric method with n-hexane:ethyl acetate (4:1) as mobile phase.

Result: The result showed that artemisinin content in plant treatment of $G$. superba seed water extract was higher $(9.78 \mu \mathrm{g} / \mu \mathrm{l}[ \pm 3.21]-16.60 \mu \mathrm{g} / \mu \mathrm{l}$ [ \pm 1.39$])$ compared to control plants $(6.39 \mu \mathrm{g} / \mu \mathrm{l}[ \pm 1.40])$. The concentration water extract of $G$. superba seed affected the level of artemisinin in the treatment plant. On the other hand, the soaking of $A$. annua L. sprouts using the water extract of $G$. superba seed did not affect the level of artemisinin content.

Conclusion: Artemisinin content in treatment plant by G. superba seed water extract treatment was higher compared to control plants.

Keywords: Artemisia annua L., Gloriosa superba, Natural colchicine

(C) 2018 The Authors. Published by Innovare Academic Sciences Pvt Ltd. This is an open access article under the CC BY license (http://creativecommons. org/licenses/by/4. 0/) DOI: http://dx.doi.org/10.22159/ajpcr.2018.v11i8.25738

\section{INTRODUCTION}

Malaria is caused by the protozoan Plasmodium parasite, which is spread by the Anopheles mosquito. Nowadays, malaria parasite has already developed chloroquine resistance, and this resistant form is now widespread throughout the world. Artemisia annua L. is a potential Chinese medicine plant that produces an active compound known as artemisinin used in malaria medication to replace quinine that has been resistant to Plasmodium falciparum. A. annua showed very remarkable antifungal activity [1]. Today, medicines produced from artemisinin derivatives are applied as a first line chemotherapy due to their high antiplasmodial efficacy and low toxicity [2].

Artemisinin content accumulates in the glandular trichomes, an organ found only in leaves, stems, and flowers [3]. Cultivation targets are directed at enhanced levels of artemisinin and high leaf production. Despite its wide distribution across the world, A. annua content of artemisinin varies greatly among herbs from different places. Improving the yield and the artemisinin content is the main objective for breeding this herb. Increased the number of chromosomes in medicinal plants is needed in order to increase its secondary metabolite level which make this medicine easily available and affordable [4]. Artificial polyploidy is a technique to increase the chromosome quantity in plant. Polyploidy can be made artificially with chemicals such as colchicine because most of these substances are easily soluble in water and effectively induce polyploidy [5]. Polyploidy induction of $A$. annua is able to increase artemisinin production [6,7]. A. annua tetraploid produces artemisinin 6 times of diploid plants [8]. A. annua polyploidy tends to have a higher content of metabolite (artemisinin) than diploid plants $[6,9,10]$. A. annua is a good candidate of new source in the development of new antimalarial drugs [11].
Gloriosa superba is a herbaceous plant that grows propagate and naturally around Krakal Beach, Gunung Kidul, Yogyakarta. Colchicine and Gloriosine are the alkaloids contained in Gloriosa superba that used in medicinal applications for treatment of gout and rheumatism. Colchicine content in G. superba as reported was ranged from $0.15 \%$ to $0.25 \%$ in the seeds [12]. The content of alkaloid colchicine compounds in $G$. superba plant can be used as a potential polyploidy mutagen [13]. G. superba is a good source of colchicine used in plant breeding studies to produce polyploidy [14].

G. superba seed water extract was used as polyploidy mutagen on $A$. annua sprouts. The aims of this research were to determine the artemisinin content on $A$. annua treated by water extract of $G$. superba seeds.

\section{METHODS}

Extraction of $G$. superba seeds

Extraction of $G$. superba seeds was using maceration method by water solvent (1:1). The water that used in this extraction was distilled water (aquadest). Analysis of colchicine content of G. superba seed extract was conducted by thin-layer chromatography (TLC)-densitometry method. Water extracts of the seeds were used as polyploidy mutagen of $A$. annua sprouts.

\section{A. annua sprouts soaking}

A. annua sprouts used were 1-2 weeks old. The treatment variables in this study were the concentration of water extracts of $G$. superba seeds $(0 \%, 25 \%, 50 \%, 75 \%$, and $100 \%)$ and the soaking time of $A$. annua sprouts ( $0 \mathrm{~min}, 30 \mathrm{~min}, 60 \mathrm{~min}$, and $90 \mathrm{~min}$ ). Design of treatment in this research is presented in Table 1. 
Table 1: Research design

\begin{tabular}{|c|c|c|c|c|}
\hline Times/concentration (\%) & a $(0 \mathrm{~min})$ & b (30 min) & c $(60 \mathrm{~min})$ & D (90 min) \\
\hline a (0) & aа & $a b$ & Ac & $\mathrm{Ad}$ \\
\hline B (25) & ba & $\mathrm{bb}$ & $\mathrm{Bc}$ & $\mathrm{Bd}$ \\
\hline C (50) & ca & $\mathrm{cb}$ & $\mathrm{Cc}$ & $\mathrm{Cd}$ \\
\hline d (75) & da & $\mathrm{db}$ & Dc & Dd \\
\hline e (100) & ea & eb & Ec & Ed \\
\hline
\end{tabular}

Table 2: Artemisinin content

\begin{tabular}{|c|c|}
\hline Leaf sample & Artemisinin content \\
\hline aa & $6.39 \mu \mathrm{g} / \mu \mathrm{l}( \pm 1.40)$ \\
\hline ba & $9.78 \mu \mathrm{g} / \mu \mathrm{l}( \pm 3.21)$ \\
\hline ca & $10.11 \mu \mathrm{g} / \mu \mathrm{l}( \pm 1.16)$ \\
\hline da & $11.65 \mu \mathrm{g} / \mu \mathrm{l}( \pm 4.28)$ \\
\hline ea & $12.67 \mu \mathrm{g} / \mu \mathrm{l}( \pm 3.79)$ \\
\hline $\mathrm{ab}$ & $7.38 \mu \mathrm{g} / \mu \mathrm{l}( \pm 4.82)$ \\
\hline $\mathrm{bb}$ & $9.89 \mu \mathrm{g} / \mu \mathrm{l}( \pm 1.68)$ \\
\hline $\mathrm{cb}$ & $10.18 \mu \mathrm{g} / \mu \mathrm{l}( \pm 6.52)$ \\
\hline $\mathrm{db}$ & $10.39 \mu \mathrm{g} / \mu \mathrm{l}( \pm 2.48)$ \\
\hline $\mathrm{eb}$ & $13.36 \mu \mathrm{g} / \mu \mathrm{l}( \pm 6.07)$ \\
\hline ac & $8.11 \mu \mathrm{g} / \mu \mathrm{l}( \pm 1.58)$ \\
\hline bc & $10.27 \mu \mathrm{g} / \mu \mathrm{l}( \pm 5.52)$ \\
\hline $\mathrm{cc}$ & $10.97 \mu \mathrm{g} / \mu \mathrm{l}( \pm 6.90)$ \\
\hline $\mathrm{dc}$ & $13.91 \mu \mathrm{g} / \mu \mathrm{l}( \pm 6.53)$ \\
\hline ec & $16.04 \mu \mathrm{g} / \mu \mathrm{l}( \pm 2.76)$ \\
\hline ad & $7.98 \mu \mathrm{g} / \mu \mathrm{l}( \pm 3.66)$ \\
\hline $\mathrm{bd}$ & $13.05 \mu \mathrm{g} / \mu \mathrm{l}( \pm 6.78)$ \\
\hline $\mathrm{cd}$ & $14.71 \mu \mathrm{g} / \mu \mathrm{l}( \pm 5.61)$ \\
\hline dd & $15.90 \mu \mathrm{g} / \mu \mathrm{l}( \pm 2.67)$ \\
\hline ed & $16.60 \mu \mathrm{g} / \mu \mathrm{l}( \pm 1.39)$ \\
\hline
\end{tabular}

Table 3: Comparison of artemisinin content in control and treated plant

\begin{tabular}{llll}
\hline A. annua & Code & Artemisinin & $\begin{array}{l}\text { Description of } \\
\text { treatment }\end{array}$ \\
\hline $\begin{array}{l}\text { Control } \\
\text { Treatment }\end{array}$ & aa & $6.39 \mu \mathrm{g} / \mu \mathrm{l}( \pm 1.40)$ & $(0 \%, 0 \mathrm{~s})$ \\
$\begin{array}{l}\text { Higher } \\
\text { Lowest }\end{array}$ & ed & $16.60 \mu \mathrm{g} / \mu \mathrm{l}( \pm 1.39)$ & $(100 \%, 90 \mathrm{~s})$ \\
\hline
\end{tabular}

\section{Extraction of $A$. annua L. leaves}

A. annua leaf sample was dried under the sun for 3 days. The dried samples are smoothed with mortar. A total of $0.1 \mathrm{~g}$ of fine leaf samples were extracted with $5 \mathrm{ml}$ of methanol and then filtered. The extraction was repeated 3 times, and the extraction results were placed on the Petri dish. The extract was evaporated using a fan until dry.

\section{Analysis of artemisinin content}

Artemisinin analysis was performed on all leaf extract samples using KLT-densitometry method. Data analysis included the data levels of colchicine in the seed water extract of $G$. superba, A. annua morphological observation, observation of $A$. annua, and level of artemisinin in $A$. annua. Chromosome observation of A. annua, stomata observation of $A$. annua and artemisinin content observation in A. annua. Observation and analysis data of chromosome and stomata A. annua using Raster Image Viewer and Opti-Lab. The research data were analyzed statistically with SPSS 16.0 using factorial ANOVA test and ANOVA General linear model. The data analysis also is a descriptive study with Microsoft office. Excel using tables and graphs. Standard artemisinin used for comparison is obtained from B2P2T00T, Tawangmangu, Karanganyar. The dried extract and standard artemisinin were precoated by silica gel $\mathrm{F}_{254}$ aluminum plate (E-Merck grade) as a narrow band with $1 \mathrm{~cm}$ width at constant rate using CAMAG Linomat. The sample on the silica plate was eluted on a mixture of n-hexane solution:ethyl acetate (4:1) as the mobile phase. The elution of $A$. annua leaf extract was observed under ultraviolet (UV) light. The Rf values and the color of the compound indicated determine the artemisinin compounds observed in UV light. Densitometric scanning was performed using a CAMAG TLC Scanner with CATS 4 software to observe the artemisinin area at selected wavelengths. The levels of artemisinin contained in A. annua leaf dry extracts were calculated from the area of the same wavelength as standard artemisinin.

\section{RESULT}

The concentration of colchicine on the water extract of $G$. superba seed used as A. annua sprout soaking mutagen was $12.84 \mu \mathrm{g} \mu \mathrm{l}$ $( \pm 2.88)$. The lowest levels of artemisinin in this study were control leaf samples of $6.39 \mu \mathrm{g} / \mu \mathrm{l}( \pm 1.40)$. The highest artemisinin content in treated plant of $16.60 \mu \mathrm{g} / \mu \mathrm{l}( \pm 1.39)$ was found in the ED leaf sample $(100 \%, 90 \mathrm{~s})$, while the lowest artemisinin content in treated plant of $9.78 \mu \mathrm{g} / \mu \mathrm{l}( \pm 3.21)$ was found in the BA leaf sample $(25 \%, 0 \mathrm{~s})$.

Analysis of artemisinin content on the soaking time of $A$. annua sprouts was not significantly different with a significance value of $\alpha \geq 0.05$, while artemisinin content analysis on concentration treatment of water extract of $G$. superba seeds was significantly different with significance value $\alpha \leq 0.05$. In this study, artemisinin content was influenced by the concentration treatment of $G$. superba seed water extract. Duncan test for concentration treatments was performed as a further test. The results showed that the concentration of $G$. superba seed water extract of $0 \%$ was significantly different on concentrations of $25 \%, 50 \%, 75 \%$, and $100 \%$.

\section{DISCUSSION}

Artemisinin content on leaf extract of A. annua that soaked with water extract of G. superba ranged from $9.78 \mu \mathrm{g} / \mu \mathrm{l}( \pm 3.21)-16.60 \mu \mathrm{g} / \mu \mathrm{l}$ $( \pm 1.39)$. There are higher than the artemisinin content in leaf extract of $A$. annua in control treatment of $6.39 \mu \mathrm{g} / \mu \mathrm{l}( \pm 1.40)$. Artemisinin content in this study increased along with the addition of $G$. superba seed water extract concentration and soaking time of $A$. annua sprouts (Table 2). Water extract of $G$. superba seed used as $A$. annua sprouts mutagen affects artemisinin levels as seen in enhanced levels of artemisinin content in all treatment plants.

Statistical analysis proved that the variable of water extract concentration of $G$. superba seeds used in the soaking of $A$. annua sprouts affects the high levels of artemisinin in the A. annua plant. The variable of soaking time of $A$. annua sprouts using water extract of $G$. superba seed did not affect the level of artemisinin. It can be concluded that the soaking time of A. annua sprouts and the increased G. superba seed water extract concentration are not correlated in the result of artemisinin level.

The content of artemisinin in A. annua was considered low; therefore, the induction of the A. annua polyploidy plant is an important stage for increasing artemisinin production [15]. In medicinal plants, leaves are often desired as a source of active compounds, so the increase in biomass associated with polyploid plants is very demanding. Larger leaf sizes in polyploid plants indicate a high biomass potential which means that the amount of the desired compound such as artemisinin 
present in the leaves can be obtained in a high concentration (Table 3) [16]

\section{CONCLUSION}

Based on the result, it shown that $A$. annua treated by water extract of $G$. superba of $12.84 \mu \mathrm{g} / \mu \mathrm{l}( \pm 2.88)$ content of colchicine influences artemisinin content. A. annua on control treatment has artemisinin levels of $6.39 \mu \mathrm{g} / \mu \mathrm{l}( \pm 1.40)$. The highest content of artemisinin leaf of $A$. annua treated by water extract of $G$. superba was $16.60 \mu \mathrm{g} / \mu \mathrm{l}( \pm 1.39)$, while lowest artemisinin content treated by water extract of $G$. superba seeds was $9.78 \mu \mathrm{g} / \mu \mathrm{l}( \pm 3.21)$. The concentration of $G$. superba seeds water extract affects the level of artemisinin, while the soaking time of A. annua does not affect the level of artemisinin.

\section{ACKNOWLEDGMENT}

This research was financially supported by Ministry of Research and Technology and Higher Education, Indonesia. The authors would like to thank Dr. Yuli Widyastuti as field supervisor from Research Center for medicinal plant and Traditional Drug, who provided seeds of A. annua.

\section{AUTHORS' CONTRIBUTION}

Sri Indah conducted the experiment and prepared the manuscript. Dr. Ari Susilowati designed the experiment and Dr. Yuli Widyastuti contributed in the experimental part of the work. Prof Ahmad Yunus designed and conducted the experiment and finalization of the manuscript.

\section{CONFLICTS OF INTEREST}

All authors confirm that this article content has no conflict of interest.

\section{REFERENCES}

1. Tilak R, Punit K, Radha R, Kashyap KD. Screening of some medicinal plants for their antimicrobial activities. Int J Pharm Sci 2015;5:206-2.

2. Ning QL, Schuehly W, Michaela von F, Frank van der Kooy. A novel purification method of artemisinin from Artemisia annua. J Ind Crops Prod 2011;34:1088-4

3. Ferreira FS, Laughlin JC, Delabays N, de Magalhaes PM. Cultivation and genetics of Artemisia annua L. forincrease production of the antimalarial artemisinin. Plant Gen Resour 2015;2:229-6.

4. Rantau DE, Hafiizh EA, Rahman W, Tri ME. Size and density analysis of stomata on Artemisia аппиа kolcisin treatment results. Proceedings of national seminar xxiii chemistry in industry and environment. Natl Sem 2014;53:52-45

5. Haryanti S, Hastuti RB, Setiari N, Banowo A. The effect of colchicine on growth, metaphase cell size and protein content of green bean seeds (Vigna radiata (L) Wilczek). Res Sci Teknol 2009;10:120-12.

6. Banyai W, Ratchada S, Netiya K, Phithak I, Masahiro M, Kanyaratt S. Overproduction of artemisinin in tetraploid Artemisia annua L. Plant Biotechnol 2010;5:433-27.

7. Huang HP, Gao SL, Chen LL, Wei KH. In vitro tetraploid and generation of tetraploids from mixoploids in Dioscorea zingiberensis. Pharmacogn Mag 2010;21:56-1.

8. Jesus-Gonzales LD, Weathers PJ. Tetraploid Artemisia annua hairy roots produce more artemisinin than diploids. Plant Cell Rep 2003;21:813-9

9. Osborn TC, Pires JA, Auger DL, Chen ZJ, Lee HS, Comai L, et al. Understanding mechanisms of novel gene expression in polyploids. Trends Genet 2003;19:147-1

10. Lin X, Zhou Y, Zhang J, Lu X, Zhang F, Shen Q, et al. Enhancement of artemisinin content in tetraploid Artemisia annua plants by modulating the expression of genes in artemisinin biosynthetic pathway. Biotechnol Appl Biochem 2011;58:50-7.

11. Aty W, Uswatun K, Lidya T, Hilkatul I, Achmad FH, Indah ST. Antimalarial activity and cytotoxicity study of ethanol extract and fraction from Alectryon serratus leaves. Int J Pharm Pharm Sci 2015;12:253.

12. Arambewela LSR, Lakhsmi SR, Kumudini MA, Ranatunga J. Studies on Gloriosa superba grown in Sri Lanka. J Nantn Sci Coun Sri Lanka 1991;2:180-77.

13. Ernawiati E. Mutagenic effect of kembang sungsang (Gloriosa superba 1 . indl.) against root cell division bulbs onion Bombay. Department of biology Fmipa university of Lampung. MIPA Sci J 2002;2:132-29.

14. Pandey DK, Banik RM. Optimization of extraction conditions for colchicine from Gloriosa superba tubers using response surface methodology. J Agric Technol 2012;4:1315-1

15. Herawati MM, Pudjihartati E, Suwijiyo, P, Endang S, Aziz P. Obtaining Artemisia cina polyploidy through plant growth regulator treatment in shoot culture. J Agrivita 2015;2:184-78.

16. Kun-Hua W, Shan-Lin G, He-Ping H. Tissue culture and generation auto-tetraploid plants of Sophora flavescens A iton. Pharmacogn Mag 2010;24:292-86 